\title{
REVIEW OF SOME PARAMETERS RELATED TO THE BASE-CUTTER OF SUGARCANE HARVESTERS
}

\author{
Abdallah M. Zein El-den ${ }^{1}$, Saad F. Ahmed ${ }^{1}$, Waleed M. Hanafy ${ }^{2}$, Abdallah E. Elwakeel ${ }^{3 \&^{*}}$ \\ ${ }^{1}$ Prof., of Ag. Eng., Fac. of Ag., Alexandria U., Alexandria, Alshatby, Egypt. \\ ${ }^{2}$ Assist. Prof., of Ag. Eng., Fac. of Ag., Aswan U., Aswan, Egypt. \\ ${ }^{3}$ Assist. Lect., of Ag. Eng., Fac. of Ag., Aswan U. Aswan, Egypt. \\ * abdallah_elshawadfy@agr.aswu.edu.eg
}

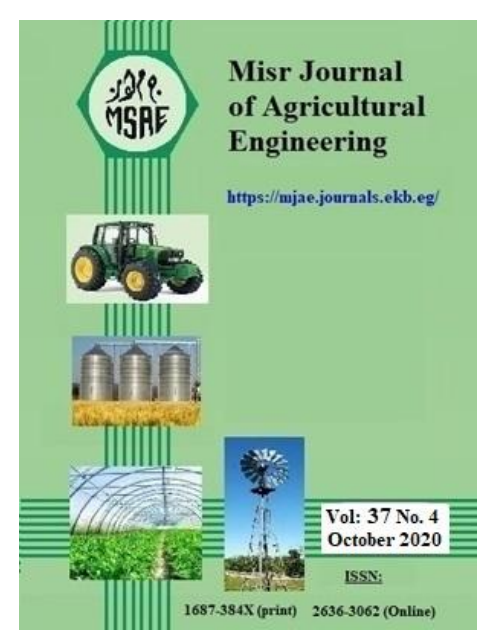

() Misr J. Ag. Eng. (MJAE)

\section{Keywords:}

Sugarcane, Physical and mechanical properties, Cutting methods, knife edges, blade angles

\section{ABSTRACT}

Sugarcane represents the main cash crop in Upper Egypt. Area cultivated with sugarcane over 300,000 feds with average production $48 \mathrm{t} / \mathrm{fed}$ and total production may reach 16 million tons. The cost of labor has been increasing where the price is uncompetitive with the cost of mechanical harvesting with imported machines. Egypt needs to change its sugarcane harvesting methods from manual harvesting to mechanization to match the development occurred in similar countries. To mechanize sugarcane harvesting. Local cheap harvester should be manufactured considering our particular conditions. The study aimed to review and conclude some parameters the base cutter of a sugarcane harvester. The parameters, many include Physical and mechanical properties of sugar cane, cutting methods and types of knife edges, blade angles for cutting blades, cutting velocity (rotational speed) and forward velocity. Several researchers have been reviewing and reporting these parameters from variable point of views and variable objectives.

\section{INTRODUCTION}

\section{$\mathbf{T}$} The parameters related to the base cutter of a sugarcane harvester: 1. Physical and mechanical properties of sugar cane:

Bosoi et al. (1996) reported that the sugarcane cutting force depends on the physical and mechanical properties of the sugarcane stalk and the thickness of the cutting blade. ElNakib et al. (1996) performed tests on the Egyptian sugar cane variety C9 and they found that the average diameter of the stalk was $2.3 \mathrm{~cm}$, and the cane stalk hardness was $775 \mathrm{~N}$. Drees, (2005) mentioned that the cutting force changed from $1272 \mathrm{~N}$ to $1140 \mathrm{~N}$ through the stalk bottom, at stalk middle decreased from 1116 to $936 \mathrm{~N}$ and at the top of stalk cutting force declined down to reach $768 \mathrm{~N}$. The maximum diameters of the cane stalks during harvest were $2.1 \mathrm{~cm}$ and $3.05 \mathrm{~cm}$ respectively at bottom and top. Taghinezhad et al. (2012) found that the maximum force increased from 313.75 to $592.74 \mathrm{~N}$ when the stalk diameters increased between $1.715-1.764$ to $2.547-2.729 \mathrm{~cm}$ at internode and it also increased from 350.30 to $811.97 \mathrm{~N}$ when the stalk diameters increased between $17.23-17.88$ to $24.49-25.35 \mathrm{~mm}$ at node. Samaila et al. (2012) reported that $401.5 \mathrm{~N}$ and $1310.35 \mathrm{~N}$ were needed for cutting the top and base of the 
sugar cane, respectively. Bastian and Shridar, (2014) stated that the maximum diameters of the cane stalks during harvest were 4 and $3.5 \mathrm{~cm}$ respectively at bottom and top based on field observations and the maximum force required for cutting a single cane at the bottom was 2698 $\mathrm{N}$ at the node and $2216 \mathrm{~N}$ at the internode. Abdel-mawla et al. (2014) make an experiment and they found that the average minimum and maximum measurements during five years as follow Stalk diameter $(2.2-2.7 \mathrm{~cm})$, Stalk weight $(0.79-0.86 \mathrm{~kg})$, stalk hardness $(325-607 \mathrm{~N})$, Compression strength $(4180-4340$ N) and cutting force $(840-886$ N). Sureshkumar and Jesudas, (2015) observed that the cutting force for cutting a single cane stalk varied between 471 and $872 \mathrm{~N}$ and the maximum lifting force measured between 105 and $300 \mathrm{~N}$ and the maximum lifting moment measured between 30.62 to 129.11 N.m.

\section{Cutting methods and types of knife edges:}

Patil and Patil, (2013) reported that the designing of the harvester cutting systems are based on two main systems: cutter bar cutting system and rotating cutting system. Rotating cutting system with blades is used more often than a cutter bar cutting system for thick stalks (such as sugar cane stalks) that have more cutting resistance. Quick, (1997) stated that the base cutter of sugar cane harvesters in use today usually consists of one or two contra-rotating discs Fig. 1 with multiple blades installed on their periphery.

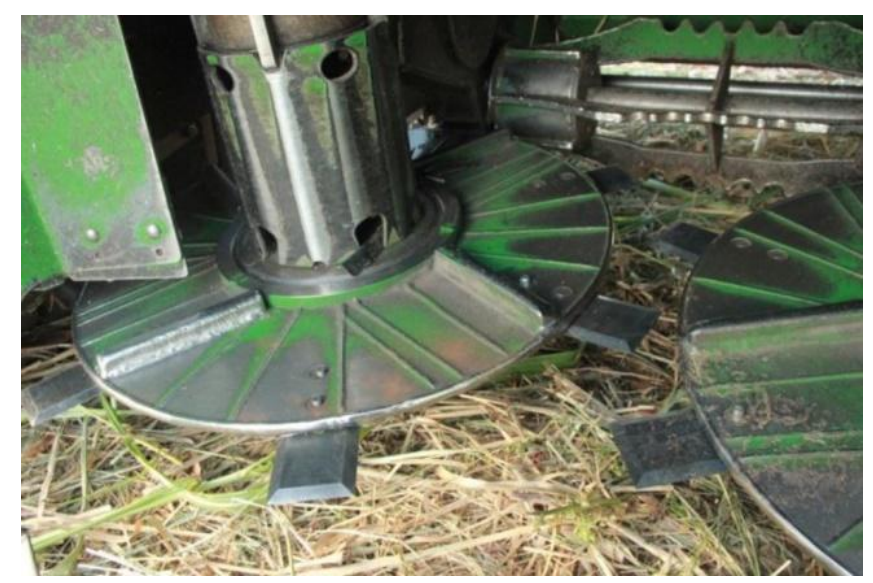

Figure 1 Base cutting unit of a John Deere 3522 sugar cane harvester. (Quick, 1997)

Frazzetta, (1988) recommended that the shape of the cutting blade is an important factor affecting the amount of cutting force and power requirement. In the cutting process of a substrate by smooth-edged blades, the ability of a blade for cutting is determined by the concentration of the cutting force onto a very small cross-section area, as shown in Fig. 2.

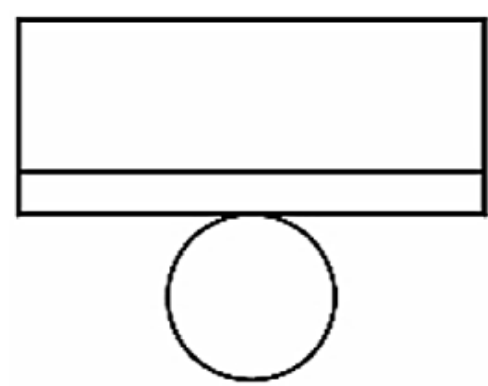

(a)

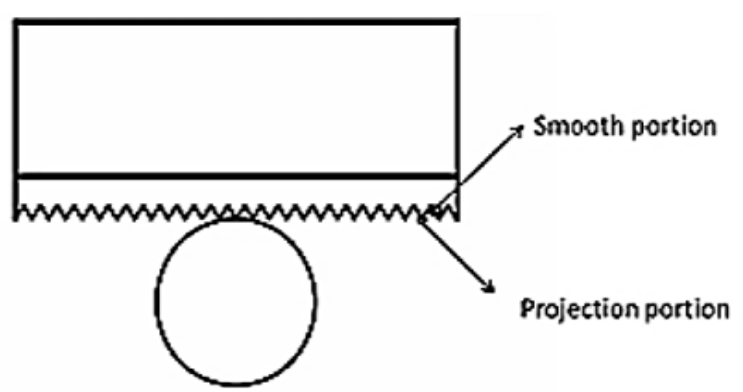

(b)

Figure 2 (a) Cutting by the smooth-edged blade; (b) cutting by the serrated blade. (Frazzetta, 1988) 
Mello and Harris, (2003) make a lab-based sugarcane cutting trial, which included two experimental factors; the length of the serration pitch and the knife shape (forward or backwardcurved), see Fig. 3; and they carried out a two-factorial experiment study to exanimate two knife shapes (forward and backward curved) of serrated-edge blades with different pitches (3 and $7 \mathrm{~mm}$ ) examining cutting energy spent for cane cutting. They concluded that the forward blade with a $3 \mathrm{~mm}$ pitch has the best result and higher energy efficiency among the experiment because more small projections make the penetration easier and cutting more effective.

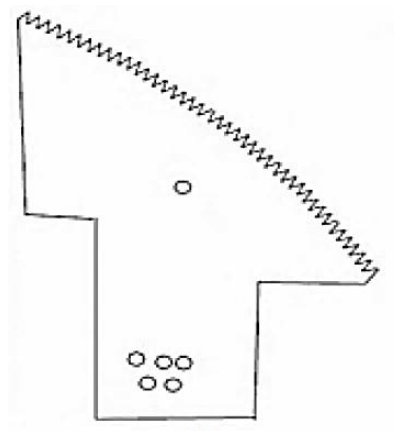

(c)

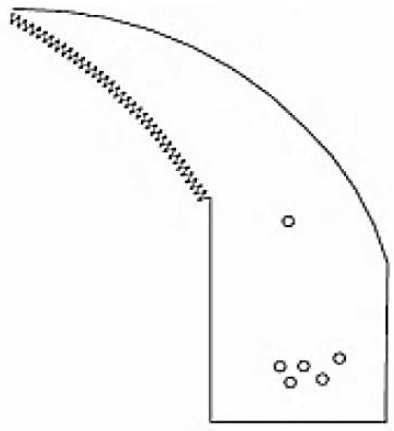

(d)

Figure 3 (c) Backward curved serrated-edge blade, (d) forward-curved serrated-edge blade. (Mello and Harris, 2003)

Mello, (2005) observed that the serrated-edge blade with serration pitch a $3 \mathrm{~mm}$ presented the lowest cutting power, but significant difference from the smooth-edge blade form, for both 450 and $600 \mathrm{r} / \mathrm{min}$ rotational velocity of the tangential speed of the cutting blades. Liu et al. (2012) found that serrated-edge blades require less cutting power and force than smooth-edged blades, and suggest that both blades may yield the desired cut quality. Mello and Harris, (2000) suggested that for minimizing the impact effect related material losses we can use a pure slicing cut action this action did not cut the sugarcane stalks but pushed it to one side; Langton and Paterson, (2004) stated that the counter shear was positioned above the blade and rotated in the opposite direction of the cutting knife. The collecting edge pulled the sugarcane stalks in toward the cutting knife where it was cut. The using of a counter shear reduced the cutting speeds and the counter shear fingers create the necessary reaction forces.

\section{Blade edge sharpening angles:}

Das and Gupta, (1972) observed that many parameters are affecting cutting resistance and cutting energy such as the edge or sharpness angle, the oblique angle $(\beta)$, the tilt angle $(\alpha)$ see Fig. 4, They concluded that the cutting force and power were minima at an edge angle of about $25^{\circ}$, a tilt angle of about $20^{\circ}$ and decreased with increasing values of the oblique angle.
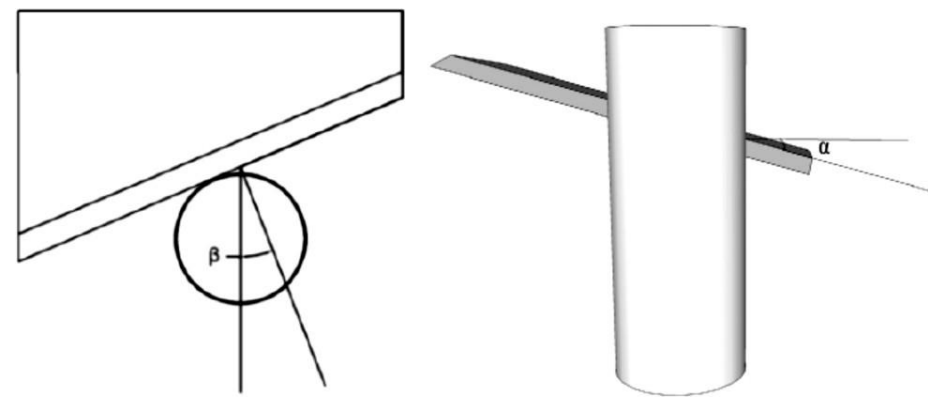

Figure 4 Schematic diagram of a cutting blade design showing the blade oblique angle $(\beta)$ and tilt angles ( $\alpha)$. (Quick, 1997) 
Gupta and Oduori, (1992) recommended that the suitable blade angles as follow: oblique angle ranged between 20 and $50^{\circ}$ and tilt angle ranged between 25 and $50^{\circ}$; They also recommended that the optimum oblique angle and tilt angle were set to $35^{\circ}$ and $27^{\circ}$ respectively. Johnson et al. (2012) carried out cutting tests and concluded that the minimum cutting energy for cutting sugarcane stalks occurred with oblique angles was $60^{\circ}$. Sureshkumar and Jesudas, (2015) reported that the cutting power was increased linearly when the oblique angle was increased from 0 to $35^{\circ}$ and was lowest at a tilt angle and oblique angle of 20 and $30^{\circ}$ respectively.

\section{Cutting velocity (rational speed of the base cutter disc) and forward velocity:}

Gupta and Oduori, (1992) reported that the optimum linear speed of the base cutter ranged from 13.8 to $18.4 \mathrm{~m} / \mathrm{s}$ and the maximum power consumption will occur when the speed of the cutting knife is more than $19.4 \mathrm{~m} / \mathrm{s}$, and they investigated that the cutting knife rotational speed should lie between 600 and $1000 \mathrm{r} / \mathrm{min}$. Liu et al. (2007) concluded that the minimum blade velocity requirement for good cutting was $22 \mathrm{~m} / \mathrm{s}$. Patil and Patil, (2013) conducted tests on the developed sugarcane cutting system and they found that the base cutter linear speed of 27 $\mathrm{m} / \mathrm{s}$. Mathanker et al. (2015) showed that cutting power increases with increasing the cutting speed. The lowest average cutting power was at a $60^{\circ}$ oblique and an average cutting speed of $7.9 \mathrm{~m} / \mathrm{s}$.

\section{CONCLUSION}

Through an in-depth study of the research that deals with studying the various factors that influence the design of sugar cane harvesting machines, it can be concluded that:

* The maximum cutting force for global sugarcane variety increased from 1272 to $2698 \mathrm{~N}$, maximum lifting force measured between 105 and $300 \mathrm{~N}$ and the maximum lifting moment measured between 30.62 to 129.11 N.m.

* The maximum cutting force for Egyptian sugarcane variety C9 increased from 840 to $886 \mathrm{~N}$ when the stalk diameters increased between 2.2 to $2.7 \mathrm{~cm}$ at stalk; maximum lifting force measured between 105 and $300 \mathrm{~N}$ and the maximum lifting moment measured between 30.62 to 129.11 N.m, stalk hardness(325-607 N), Compression strength (4180-4340 N).

* Rotating cutting system with blades is appropriate cutting methods for cutting sugar cane stalk.

* The serrated-edge blades had better cutting quality, cutting force required and cutting power than smooth blades, but the material loss was greater.

* The forward blade has the best result and higher energy efficiency.

* The suitable blade angles as follow: oblique angle ranged between 20 and $50^{\circ}$, tilt angle ranged between 25 and $50^{\circ}$, with edge (sharpness) angle $25^{\circ}$; noting that the cutting power will increase linearly when the oblique angle increasing.

* The linear speed of the base cutter ranged from 7.9 to $27 \mathrm{~m} / \mathrm{s}$, and forward speed of the sugarcane harvester for low and high fiber sugarcane varieties should be $14 \mathrm{~m} / \mathrm{s}$ and 17 .

\section{REFERENCES}

Bastian. J., and B. Shridar, (2014). "Investigation on Mechanical Properties of Sugarcane Stalks for the Development of a Whole Cane Combine Harvester", Indian journal of applied research, 4 (9), pp. 1-3.

Bosoi, E. S., et al. (1991). "Theory, Construction, and Calculation of Agriculture Machines", Volume Two. A.A. Balkema/Rotterdam: pp. 323-347. 
El-Nakib, A. A., et al. (1996). "Physical properties of sugar cane: their relation to mechanization. MSAE exploration of modem tech", In field of Agric. Eng. ${ }^{\text {th }}$ Conference of Misr Society of Ag. Eng., 28 October 13(4), pp. 63-78.

Drees, A. M. (2005). "A Study on Mechanization of Sugar Cane Planting, Fabricating a Seedling Preparation Unit and Performance Evaluation of Transplanting Machine for Sugar Cane Crop", Ph.D. thesis Agric. Mech. Dept.

Taghinezhad, J., et al. (2012). "Effect of Sugarcane Stalks' Cutting Orientation on Required Energy for Biomass Products", Internatıonal Journal of Natural and Engineering Sciences 6 (3), pp. 47-53, 2012 ISSN: 1307-1149, E-ISSN: 2146-0086.

Samaila, S., et al. (2012). "Development of a Tool to Determine the Energy Required to Cut and Top Sugarcane”, AU J.T. 16(1), pp. 59-62.

Abdel-mawla, H. A., et al. (2014). "Field evaluation and crop conditions related to sugar cane mechanical harvesting”, Egypt. J. Agric. Res., 92(1), pp. 257-271.

Sureshkumar, P. K., and Jesudas, D. M. (2015). "physico-mechanical properties of sugar cane stalks related to mechanical harvesting", Journal of Tropical Agriculture 53 (1), pp. 4855 .

Patil, M., and Patil, P. D. (2013). "Optimization of Blade Angle for Cutting System of Sugar Cane Harvester", International Indexed \& Refereed Research Journal, March, ISSN 0975-3486, E-ISSN- 2320-5482,

Quick, D. J. (1977). "Base cutting apparatus for sugar cane harvesters", U.S. Patent No. $4,019,308$.

Frazzetta, T. (1988). "The mechanics of cutting and the form of shark teeth (Chondrichthyes, Elasmobranchii)", Zoomorph., 108(2), pp. 93-107.

Mello, R. D. C., and Harris, H. (2000). "Cane damage and mass losses for conventional and serrated base cutter blades", Proc. Conf. Australian Soc. Sugar Cane Tech. (pp. 84-91). Bundaberg, Australia: PK Editorial Services Pty Ltd.

Mello, R. D. C., and Harris, H. (2003). "Performance of base cutter of sugarcane harvester with angled and serrated blades", Revista Brasileira de Engenharia Agrícola e Ambiental, 7(2), pp. 355-358.

Mello, R. D. C. (2005). "Effect of blade shape and speed on cutting forces for sugar cane", Acta Scientiarum: Agronomy 27, pp. 661-665 (in Portuguese, with abstract in English).

Liu, Q., et al. (2012). "Biomechanical properties of miscanthus stems", Transactions of the ASABE 55, pp. 1125-1131.

Langton, M. I., and Paterson, J. W. S. (2004). “Alternative Sugarcane Harvesting Methods", Final year design report, School of Bio-resources Engineering \& Environmental Hydrology, University of KwaZulu-Natal, Pietermaritzburg, 121 p.

Das, F. C., and Gupta, C. P. (1972). "Cutting resistance of sugar cane stem", Presented at the $10^{\text {th }}$ annual meeting of the Indian Society of Agricultural Engineers at Jabalpur, India, 35 Feb.

Gupta, C., and Oduori, F. (1992). "Design of the revolving knife-type sugarcane base cutter", Transactions of the ASABE, 35(6), pp. 1747-752.

Liu, Q., et al. (2007). "Stubble damage of sugarcane stalks in cutting tests by a smooth-edge blade", Trans. Chinese Soc. Agric. Eng., 23(3), pp. 103-107.

Mathanker, S. K., et al. (2015). "Effect of blade oblique angle and cutting speed on cutting energy for energy cane stems", Bio-systems Engineering 133, pp. 64-70. 


\section{استعر اض مرجعي لبعض العوامل المتعلقة بآلية قطع القاعدة بآلات حصاد القصب}

أ.د/ عبد الله مسعد زين الدين'، أ.د/ سعد فتح الله أحمد'، د/وليل محمد حنفي و م/ عبد الله الثوادفي الوكيلب

' استاذ الهندسة الزر اعية ـ كلية الزر اعة ـ جامعة الاسكندرية ـ الاسكندرية ـ الثاطبي ـ مصر.

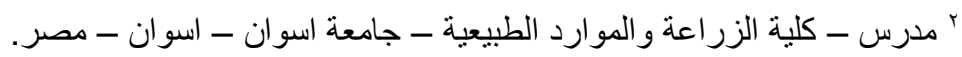

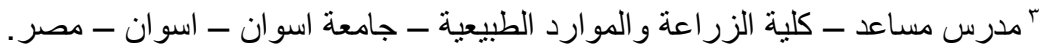

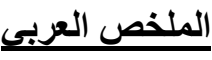

أجري هذا البحث بهدف عمل در اسة مرجعية للتعرف على العو امل المختلفة التي تؤثر

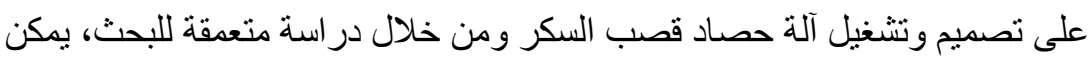

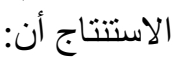

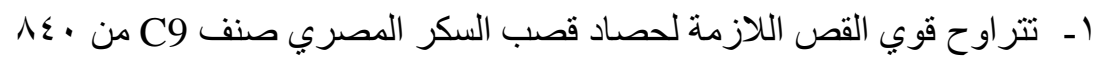

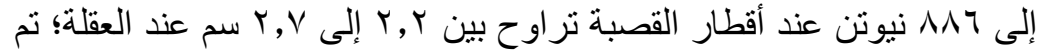

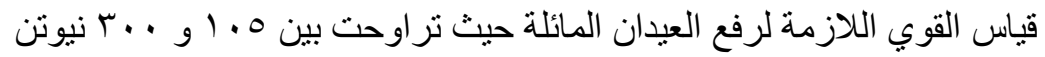

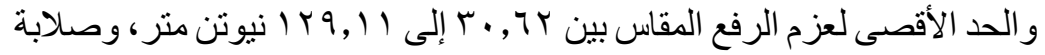

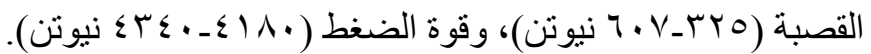

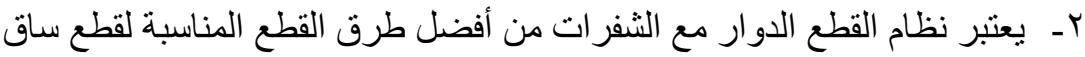

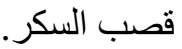
rــ ت تمناز السكاكين ذات الحافة المسننة بجودة قطع أفضل و أقل قوة قطع مطلوبة لكن لها نسبة فاقد اعلي.

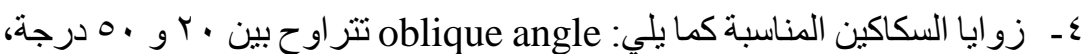

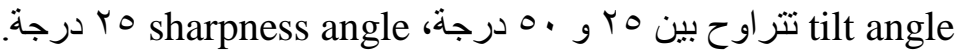

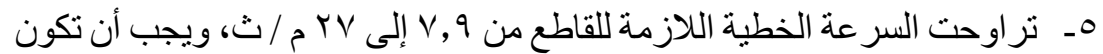
السر عة الأمامية لحصاد قصب السكر لأصناف قصب السب السكر المنخفضة والعالية

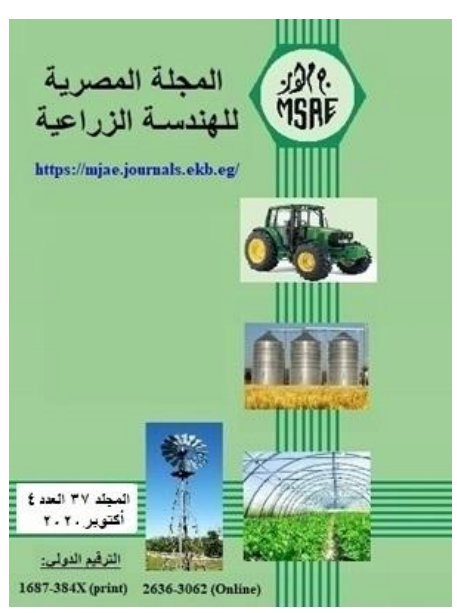

C المجلة المصرية للهندة الزراعية

الكلمات المقتاحية: قصب السكر، الخصائص الطبيعية والميكانيكية، طرق القطع، حواف السكاكين، زو ايا الثفر ات طرون 